Journal of Molecular Microbiology and Biotechnology

Vol. 14, No. 1-3, 2008 ; P107-114

http://dx.doi.org/10.1159/000106089

(C) 2007 S. Karger AG, Basel
Archimer, archive institutionnelle de l'ffremer http://www.ifremer.fr/docelec/

This paper is the pre-print version submitted by the author to the Editor - before peer review - the $17^{\text {th }}$ May, 2006. The final article (J. Mol. Microbiol. Biotechnol. 14 (1-3), 2008, P107-114) is copyright protected. Any distribution without written consent from S. Karger AG, Basel is a violation of the copyright.

\title{
Updating the importance of lactic acid bacteria in fish farming: natural occurrence and probiotic treatments.
}

\author{
François-Joël Gatesoupe
}

INRA-Ifremer, Joint Research Unit for Fish Nutrition, Aquaculture \& Genomics, Plouzané, France

Address :Ifremer, Centre de Brest, BP 70, F-29280 Plouzané, France

Tel. +33 2982243 89, Fax +33 2982243 66, E-mail joel.gatesoupe@ifremer.fr

Running title: Importance of lactic acid bacteria in fish farming

\begin{abstract}
Many recent papers have deepened the state of knowledge about lactic acid bacteria (LAB) in fish gut. In spite of high variability in fish microbiota, LAB are sometimes abundant in the intestine, notably in freshwater fish. Several strains of Streptococcus are pathogenic to fish. S. iniae and Lactococcus garvieae are major fish pathogens, against which commercial vaccines are available. Fortunately, most LAB are harmless, and some strains have been reported for beneficent effects on fish health. A major step forward of the recent years was those converging evidences that LAB can stimulate the immune system in fish. An open question is whether viability can affect immunostimulation. The issue is crucial to commercialise live probiotics rather than inactivated preparations or extracts. There was a regain of interest in allochthonous strains used as probiotics for terrestrial animals or human, due to economical and regulatory constraints, but the short survival in seawater may limit application to marine fish. If viability is required, alternative treatments may be the incorporation of prebiotics in feed, and other dietary manipulations that could promote intestinal LAB. Antagonism to pathogens is the other main feature of candidate probiotics, and there are many reports concerning mainly carnobacteria and Enterococcus. Some bacteriocins were characterized, which may be of interest not only for aquaculture, but also for food preservation.
\end{abstract}

Keywords: Fish · Gastrointestinal microbiota - Lactic acid bacteria · Pathogen · Probiotic 


\section{Introduction}

Aquaculture is a fast growing industry, which represented one third of the world fisheries production in 2003 [Lowther, 2005]. The intensification of fish culture has caused the emergence of new pathogens, and the need for sustainable treatments and prophylactic measures. The interest of lactic acid bacteria ( $L A B)$ was highlighted in these regards, as the group includes fish pathogens, and also candidate probiotics that could improve fish health [Ringø and Gatesoupe, 1998]. In the meantime, the state of knowledge on fish gastrointestinal microbiota has amplified, and it may be opportune to update the importance of LAB in fish culture, in the light of recent advances. The reader is referred to the previous review [Ringø and Gatesoupe, 1998], while the present paper focused on fresh literature. In the recent years, the progress in molecular microbiology led to reassign the place of the bacterial group in microbiota. While new pathogens emerged, some vaccines have been commercialised, and many LAB have been tested for their probiotic potential.

\section{Variability in natural occurrence}

One of the most important features of gastrointestinal microbiota in fish is variability. Spanggaard et al. [2000] compared the intestinal microflora of rainbow trout in three different farms. These authors found Carnobacterium spp. dominant among the culturable isolates in one farm at one sampling date, but this genus was detected neither at another date in the same farm, nor in the other farms. Parallel samples were taken in the same three farms at the same dates for FISH and DGGE analyses, which led to different images of the bacterial community, while not culturable bacteria were found dominant in one fish [Huber et al., 2004]. This example illustrated the difficulty to delineate the actual incidence of $L A B$ in fish intestine, but they are sometimes abundant. For instance, Cai et al. [1999] estimated LAB counts to $10^{7}-10^{8} \mathrm{CFU} / \mathrm{g}$ in the intestine of common carp, mainly identified as Lactococcus garvieae, and also Pediococcus acidilactici and Enterococcus faecium. Diversity was particularly studied in freshwater fish [Cai et al., 1999; González et al., 2000; Hagi et al., 2004; Bucio et al., 2006], but LAB are also present in marine fish. Seppola et al. [2006] characterized as carnobacteria all the culturable isolates from the hindgut chamber of Atlantic cod, to which they ascribed a role of fermentation chamber.

Environmental fluctuations seemed the main cause of the variability observed in fish microbiota. Al-Harbi and Uddin [2003] showed the similarity of bacterial communities in sediment, freshwater and hybrid tilapia, though Streptococcus sp. was more abundant in brackish water and in Nile tilapia than in the pond sediment [Al-Harbi and Uddin, 2005]. Fish are poikilotherms, and temperature seemed the main cause of seasonal variation [Bucio et al., 2006]. Hagi et al. [2004] observed a shift from Lactococcus raffinolactis to Lactococcus lactis in fish intestine in summer, when temperature was above $20^{\circ} \mathrm{C}$. The diet is also known to affect intestinal LAB. Ringø and Olsen [1999] isolated Carnobacterium divergens from the intestine of Artic charr fed a low-carbohydrate diet, whereas other species of Carnobacterium were identified in fish fed wheat meal. Ringø et al. [2002a] noted that Artic charr fed vegetable oil hosted Carnobacterium spp., unlike those fed with marine oil. Furthermore, some of these strains were found antagonistic to pathogens, possibly improving the resistance of fish to disease. These studies are particularly interesting in front of the need to replace fishmeal and fish oil in aqua feeds, due to resource shortage. The novel diets may thus affect microbiota in fish, and the interaction with fish health should be further investigated.

\section{Pathogens}

Two vaccines have been commercialised against the two major LAB pathogenic to fish, Lactococcus garvieae and Streptococcus iniae [Sommerset et al., 2005]. L. garvieae has many biovars, either pathogenic [Eldar et al., 1999] or not [Cai et al., 1999]. The efficiency of the vaccine may be affected by environmental conditions, e.g. the effect of salinity on barramundi vaccination against S. iniae [Delamare-Deboutteville et al., 2006]. Many fish species are 
affected by these two major pathogens [Buller, 2004], and streptococcosis can spread with wild fish [Colorni et al., 2002]. Several other species of Streptococcus comprise fish pathogens [Buller, 2004]. S. agalactiae seemed of particular concern among the emerging epizootics [Evans et al., 2002], and a new vaccine has been proposed [Evans et al., 2004; Pasnik et al., 2005a, b , 2006]. Carnobacterium piscicola has been also frequently isolated from fish, but few strains seemed highly virulent [Buller, 2004]. Other genera of LAB have strains pathogenic to fish, but the incidence of the disease seemed generally limited to one fish species, or to one region, like Vagococcus salmoninarum, an emerging pathogen to rainbow trout in Europe [RuizZarzuela et al., 2005].

Though pathogenic strains are generally specific, some risk for human health might be caused by LAB harboured by fish. Virulence factors seemed widely distributed among the genus Enterococcus, and Semedo et al. [2003] recommended to screen for virulence even familiar strains before use by high risk population groups. Streptococcus phocae, a pathogen for aquatic mammalians was isolated from clinical specimens of Atlantic salmon [Gibello et al., 2005]. The pathogeny has not been clearly established yet for salmon, but they could contaminate seals and other predators. Besides pathogenic strains, an overhanging threat is the spread antibiotic resistance due to livestock. Integrated broiler-fish farming seemed to increase the number of resistant isolates of Enterococcus spp., in comparison with farm culturing fish only [Petersen and Dalsgaard, 2003].

\section{Autochthonous probiotics}

L. garviae and C. piscicola were used as test pathogens to select candidate probiotics for fish among the intestinal bacteria with antagonistic features [Sugita et al., 2002; Vine et al., 2004]. Brunt and Austin [2005] protected rainbow trout against pathogenic L. garviae and S. iniae by incorporating into the feed an antagonistic strain of Aeromonas sobria, which stimulated the immune system of the trout. Limited protection was observed with the inactivated probiotic, but the live cells were the most effective.

Most LAB are harmless, and some strains are beneficent for fish health. The genus Carnobacterium was found particularly rich in strains antagonistic to pathogens, for instance many C. piscicola-like isolates from the gut of Atlantic salmon and Artic charr inhibited the growth of Aeromonas salmonicida [Ringø et al., 2000, 2001]. Other isolates from gills of Atlantic salmon inhibited also A. salmonicida and Vibrio anguillarum [Ringø and Holzapfel, 2000]. Ringø et al. [2001] characterized Carnobacterium divergens isolates from the intestine of Atlantic salmon, Atlantic cod and wolf fish with inhibitory activity against $A$. salmonicida, like another strain from Arctic charr, which was also antagonistic to $V$. anguillarum and Vibrio viscosus [Ringø et al., 2002b]. It must be kept in mind that an in-vitro inhibition does not necessarily mean that the candidate probiotic will work in-vivo. Antagonistic Carnobacterium spp. did not protect against $V$. anguillarum the fish from where they were isolated, Atlantic cod or rainbow trout [Gildberg and Mikkelsen, 1998; Spanggaard et al., 2001]. Mortality was delayed during the challenge test when cod were fed a diet supplemented with another strain of $C$. divergens, isolated from Atlantic salmon [Gildberg and Mikkelsen, 1998]. The same strain was tested on turbot larvae challenged with Vibrio pelagius, but there was no improvement of survival [Ringø, 1999]. Carnobacterium inhibens isolated from Atlantic salmon [Jöborn et al., 1999] reduced mortality of the salmon and rainbow trout challenged with $A$. salmonicida, Vibrio ordalii and Yersinia ruckeri, but not $V$. anguillarum [Robertson et al., 2000]. Carnobacterium sp. BA211, isolated from rainbow trout, was found superior to $C$. inhibens for protecting the trout against $A$. salmonicida [Irianto and Austin, 2002]. Strain BA211 stimulated the immune system, and this was likely the main mode of action, since inactivated cells protected the trout against furunculosis [Irianto and Austin, 2003]. The inactivation seemed to decrease the effects on cellular immunity, except for the number of leucocytes, which was much greater with the inactivated form than with the live probiotic. The protection worked in 15-30 g juveniles, but not in 1-2 $\mathrm{g}$ fry. However, These challenge experiments did not reflect exactly what could happen in normal rearing conditions. In particular, the pathogen has been generally injected intraperitoneally to improve the repeatability of the test. The method is relevant to investigate the immune response after infection, but there is no information about the primary defenses against the infection in case of intestinal route. The importance of antagonism may be thus 
underestimated, and the efficiency of candidate probiotics will need long-term application in fish farms to be validated.

Besides carnobacteria, few other LAB were tested as probiotics. For instance, Weisella hellenica isolated from the Japanese flounder was antagonistic to Edwarsiella tarda, Pasteurella piscicida, Aeromonas hydrophila, and $V$. anguillarum, but not Streptococcus faecalis [Cai et al., 1998]. When the candidate probiotic was added to the diet, the flounder had a higher growth than the control group, while less bacteria were counted in the intestine of the experimental group [Byun et al., 1997]. The survival of Atlantic halibut larvae was improved after incubation with Lactobacillus plantarum isolated from Atlantic cod, and the proliferation of mucous cells suggested a stimulation of cellular defenses [Ottesen and Olafsen, 2000].

Three strains of $C$. piscicola isolated from salmonid intestine (V1) and cold-smoked salmon (SF668, A9b) were investigated for their production of bacteriocin for biopreservation of fish products [Nilsson et al., 2002; Brillet et al., 2004]. The three Strains were bactericidal to Listeria monocytogenes [Duffes et al., 1999; Duffes et al., 2000; Nilsson et al., 2002]. C. divergens V41 from salmonid intestine produced another bacteriocin, which seemed particularly promising for food protection [Métivier et al., 2000; Connil et al. 2002a, b; Brillet et al., 2004, 2005]. Three other bacteriocin producing $L A B$ from turbot flesh inhibited $L$. monocytogenes and Staphylococcus aureus (Lactococcus lactis, Enterococcus faecium, and Enterococcus mundtii [Campos et al., 2006]). These heat-resistant bacteriocins worked in acidic conditions, and they may be of particular interest for processed food. Three other strains of the genus Enterococcus were isolated from the intestine of Prochilodus argenteus, with antagonistic properties against a wide range of bacteria [Silva et al., 2005]. Pediococcus sp. isolates from rohu fish intestine were also antagonistic to Bacillus cereus, Escherichia coli, and S. aureus, but the inhibitory cell-free supernatants should be treated with protease to confirm whether the effect was due to the bacteriocin production hypothesized by Halami et al. [1999]. Bacteriocin production can play a role in the antagonistic modes of action of probiotics, but the production of organic acids like lactic and acetic acids may be crucial too, according Vázquez et al. [2005] who tested turbot pathogens against allochthonous LAB in vitro. Tomé et al. [2006] confirmed that organic acids could account for the inhibitory activity of LAB in smoked salmon.

\section{Allochthonous probiotics}

Autochthonous bacteria may be a source of peculiarly fitted probiotics, but there has been regain of interest for the allochthonous strains that were already approved as probiotics for land animals or human, due to regulatory constraints [Gatesoupe, 2005]. Nikoskelainen et al. [2001a] evaluated seven such LAB strains by considering their adherence and penetration into fish mucus, their inhibition of pathogen growth and adhesion, and their resistance to fish bile. Lactobacillus rhamnosus and Lactobacillus bulgaricus were selected as the best candidate probiotics for rainbow trout. Mortality was significantly reduced when the trout were fed a diet supplemented with a high dose of $L$. rhamnosus $\left(10^{12}\right.$ CFU/g) [Nikoskelainen et al., 2001b]. The gastrointestinal tract was progressively colonized by the probiotic during one month of experimental feeding with a wide range of dosages $\left(10^{4}-10^{11} \mathrm{CFU} / \mathrm{g}\right.$ feed [Nikoskelainen et al., 2003]), up to becoming dominant in the culturable flora [Panigrahi et al., 2004]. Meanwhile, the immune system was stimulated [Nikoskelainen et al., 2003; Panigrahi et al., 2004]. As for Carnobacterium sp., the viability of the probiotic affected the immune response, and the heatkilled cells were less efficient than the live preparation [Panigrahi et al., 2005]. One or two weeks after probiotic treatment, the immune system came back to initial status [Nikoskelainen et al., 2003; Panigrahi et al., 2005]. A similar trend of immunostimulation was observed in gilthead seabream fed live Lactobacillus delbrüecki [Salinas et al., 2005]. In this experiment, the viability of the probiotic was not checked in the intestine, but strong stimulation of seabream headkidney leucocytes was observed in-vitro with heat-inactivated L. delbrüecki [Salinas et al., 2006]. Villamil et al. [2002] showed the adhesion of Lactococcus lactis to turbot intestinal mucus in-vitro, and the antagonism to fish pathogens. The intestinal colonization seemed low in turbot fed the probiotic, but heat-killed cells of $L$. lactis stimulated the immune response [Villamil et al., 2002]. Allochthonous probiotics act therefore on the immune system of marine juvenile fish, but the viability did not seem essential, and their colonization potential needs confirmation in vivo. Vázquez et al. [2003] estimated between 3 and $21 \mathrm{~h}$ the half lives of allochthonous LAB in 
seawater $(35 \mathrm{~g} / \mathrm{l})$ at $20-30^{\circ} \mathrm{C}$. This short survival time may not be favourable for colonization in marine fish, though probiotics kept alive in fish larvae fed live food organisms. Pediococcus acidilactici was relatively resistant to salinity [Vázquez et al., 2003], and it was retrieved in high numbers in larval pollack fed Artemia treated with the probiotic $\left(10^{5} \mathrm{CFU} /\right.$ larva [Gatesoupe, 2002]). Lactobacillus plantarum was similarly counted in gilthead seabream larvae before weaning $\left(10^{4} \mathrm{CFU} / \mathrm{g}\right.$ larvae [Carnevali et al., 2004]). In this later experiment, Artemia were concomitantly treated with the allochthonous probiotic, and an autochthonous strain of Lactobacillus fructivorans, which colonised naturally the gut of seabream since weaning. By the end of the experiment, the counts of $L$. fructivorans in the fry fed the probiotics were one log higher than those of the control group $\left(10^{3}-10^{4} \mathrm{CFU} / \mathrm{g}\right.$ larvae). L. plantarum was not retrieved after weaning, though both probiotics were still supplied via the compound diet. This combined treatment increased fry survival, but it was not possible to know whether the effect was due to one or both probiotics. However, the number of immunocompetent cells associated with the gut was increased by this combined treatment [Picchietti et al., 2006]. A commercial preparation with four probiotics, including Lactobacillus acidophilus, was also tested on the Japanese flounder [Taoka et al., 2006]. The consortium improved water quality, lysozyme activity, and resistance against heat shock and $V$. anguillarum infection. There was no evidence that the LAB contributed to these effects. Synergy may be expected from such association of probiotics, but that should be further investigated by comparing the effects of the single and multiple treatments.

Several allochthonous probiotics affected intestinal microbiota in freshwater fish, with various consequences on health and rearing performances. $P$. acidilactici limited the incidence of the vertebral column compression syndrome in rainbow trout [Aubin et al., 2005]. Enterococcus faecium protected European eel challenged with Edwardsiella tarda [Chang and Liu, 2002]. Some probiotic LAB were qualified as growth promoters, like Streptococcus faecium for common carp [Bogut et al., 1998], E. faecium for Silurus glanis [Bogut et al., 2000], or a commercial mix with S. faecium and Lactobacillus acidophilus for Nile tilapia [Lara-Flores et al., 2003]. In this later case, it was not possible to discriminate the efficiency of the two strains. The same remark applies to another commercial consortium with Lactobacillus coagulans and Saccharomyces cerevisiae, which stimulated the growth of Indian carps, Catla catla and Cirrhinus mrigala [Mohanty et al., 1996; Swain et al., 1996].

\section{Conclusion}

A major step for the rational use of $L A B$ in aquaculture was brought by the converging evidences of their effects on the immune system of fish. However, many questions are open before practical application. Bricknell and Dalmo [2005] proposed the pulse administration of immunostimulants to avoid possible adverse effects of continuous supply. The long term effects of $L A B$ as dietary supplement are still unknown, and the optimum duration of treatment should be estimated. Whether viability is essential for health benefits should be further investigated by comparing the effects of live probiotics to those of inactivated cells, cellular fractions, culture supernatants, and purified compounds like bacteriocins or organic acids. Where viability would be required, the commercialisation of new probiotics may be hindered by economical and regulatory impediments, especially with unfamiliar autochthonous strains, which should be certified exempt from virulence factors. Thus, the prebiotic approach may be worth developing too, but the applicability to fish awaits confirmation [Burr et al., 2005; Gatesoupe, 2005]. It may be worth exploring new aqua feed ingredients for their richness in carbohydrates that could be fuelled selectively by LAB. 


\section{References}

Al-Harbi AH, Uddin N: Quantitative and qualitative studies on bacterial flora of hybrid tilapia (Oreochromis niloticus x O. aureus) cultured in earthen ponds in Saudi Arabia. Aquac Res 2003;34:43-48.

Al-Harbi AH, Uddin N: Bacterial diversity of tilapia (Oreochromis niloticus) cultured in brackish water in Saudi Arabia. Aquaculture 2005;250:566-572.

Aubin J, Gatesoupe FJ, Labbé L, Lebrun L: Trial of probiotics to prevent the vertebral column compression syndrome in rainbow trout (Oncorhynchus mykiss Walbaum). Aquac Res 2005;36:758-767.

Bogut I, Milakovic Z, Bukvic Z, Brkic S, Zimmer R: Influence of probiotic (Streptococcus faecium M74) on growth and content of intestinal microflora in carp (Cyprinus carpio). Czech J Anim Sci 1998;43:231-235.

Bogut I, Milakovic Z, Brkic S, Novoselic D, Bukvic Z: Effects of Enterococcus faecium on the growth rate and content of intestinal microflora in sheat fish (Silurus glanis). Vet Med-Czech 2000;45:107-109.

Bricknell I, Dalmo RA: The use of immunostimulants in fish larval aquaculture. Fish Shellfsh Immunology 2005;19:457-472.

Brillet A, Pilet MF, Prevost H, Bouttefroy A, Leroi F: Biodiversity of Listeria monocytogenes sensitivity to bacteriocin-producing Carnobacterium strains and application in sterile coldsmoked salmon. J Appl Microbiol 2004;97:1029-1037.

Brillet A, Pilet MF, Prevost H, Cardinal M, Leroi F: Effect of inoculation of Carnobacterium divergens $\mathrm{V} 41$, a biopreservative strain against Listeria monocytogenes risk, on the microbiological, chemical and sensory quality of cold-smoked salmon. Int J Food Microbiol 2005;104:309-324.

Brunt J, Austin B: Use of a probiotic to control lactococcosis and streptococcosis in rainbow trout, Oncorhynchus mykiss (Walbaum). J Fish Dis 2005;28:693-701.

Bucio A, Hartemink R, Schrama JW, Verreth J, Rombouts FM: Presence of lactobacilli in the intestinal content of freshwater fish from a river and from a farm with a recirculation system. Food Microbiol 2006;23:476-482.

Buller NB: Bacteria from Fish and Other Aquatic Animals: A Practical Identification Manual. Wallingford, UK, CABI Publishing, 2004.

Burr G, Gatlin D, Ricke S: Microbial ecology of the gastrointestinal tract of fish and the potential application of prebiotics and probiotics in finfish aquaculture. $\mathrm{J}$ World Aquacult Soc 2005;36:425-436.

Byun JW, Park SC, Benno Y, Oh TK: Probiotic effect of Lactobacillus sp. DS-12 in flounder (Paralichthys olivaceus). J Gen Appl Microbiol 1997;43:305-308.

Cai Y, Benno Y, Nakase T, Oh TK: Specific probiotic characterization of Weissella hellenica DS12 isolated from flounder intestine. J Gen Appl Microbiol 1998;44:311-316.

Cai Y, Suyanandana P, Saman P, Benno Y: Classification and characterization of lactic acid bacteria isolated from the intestines of common carp and freshwater prawns. J Gen Appl Microbiol 1999;45:177-184.

Campos CA, Rodríguez O, Calo-Mata $\mathrm{P}$, Prado M, Barros Velázquez J: Preliminary characterization of bacteriocins from Lactococcus lactis, Enterococcus faecium and Enterococcus mundtii strains isolated from turbot (Psetta maxima). Food Res Int 2006;39:356-364.

Carnevali O, Zamponi MC, Sulpizio R, Rollo A, Nardi M, Orpianesi C, Silvi S, Caggiano M, Polzonetti AM, Cresci A: Administration of probiotic strain to improve sea bream wellness during development. Aquac Int 2004;12:377-386.

Chang Cl, Liu WY: An evaluation of two probiotic bacterial strains, Enterococcus faecium SF68 and Bacillus toyoi, for reducing edwardsiellosis in cultured European eel, Anguilla anguilla L. J Fish Dis 2002;25:311-315.

Colorni A, Diamant A, Eldar A, Kvitt H, Zlotkin A: Streptococcus iniae infections in Red Sea cage-cultured and wild fishes. Dis Aquat Organ 2002;49:165-170.

Connil N, Plissoneau L, Onno B, Pilet MF, Prevost H, Dousset X: Growth of Carnobacterium divergens V41 and production of biogenic amines and divercin V41 in sterile cold-smoked salmon extract at varying temperatures, $\mathrm{NaCl}$ levels, and glucose concentrations. J Food Protect 2002a;65:333-338. 
Connil N, Prevost H, Dousset X: Production of biogenic amines and divercin V41 in cold smoked salmon inoculated with Carnobacterium divergens V41, and specific detection of this strain by multiplex-PCR. J Appl Microbiol 2002b;92:611-617.

Delamare-Deboutteville J, Wood D, Barnes AC: Response and function of cutaneous mucosal and serum antibodies in barramundi (Lates calcarifer) acclimated in seawater and freshwater. Fish Shellfish Immunol 2006;21:92-101.

Duffes F, Corre C, Leroi F, Dousset X, Boyaval P: Inhibition of Listeria monocytogenes by in situ produced and semipurified bacteriocins of Carnobacterium spp. on vacuum-packed, refrigerated cold-smoked salmon. J Food Protect 1999;62:1394-1403.

Duffes F, Leroi F, Dousset X, Boyaval P: Use of a bacteriocin producing Carnobacterium piscicola strain, isolated from fish, to control Listeria monocytogenes development in vacuum-packed cold-smoked salmon stored at 4 degrees C. Sci Aliment 2000;20:153-158.

Eldar A, Goria M, Ghittino C, Zlotkin A, Bercovier H: Biodiversity of Lactococcus garvieae strains isolated from fish in Europe, Asia, and Australia. Appl Environ Microbiol 1999;65:1005-1008.

Evans JJ, Klesius PH, Gilbert PM, Shoemaker CA, Al Sarawi MA, Landsberg J, Duremdez R, Al Marzouk A, Al Zenki S: Characterization of beta-haemolytic Group B Streptococcus agalactiae in cultured seabream, Sparus auratus L., and wild mullet, Liza klunzingeri (Day), in Kuwait. J Fish Dis 2002;25:505-513.

Evans JJ, Klesius PH, Gilbert PM, Shoemaker CA: Efficacy of Streptococcus agalactiae (group B) vaccine in tilapia (Oreochromis niloticus) by intraperitoneal and bath immersion administration. Vaccine 2004;22:3769-3773.

Gatesoupe FJ: Probiotic and formaldehyde treatments of Artemia nauplii as food for larval pollack, Pollachius pollachius. Aquaculture 2002;212:347-360.

Gatesoupe FJ: Probiotics and prebiotics for fish culture, at the parting of the ways. Aqua Feeds: Formulation \& Beyond 2005;2(3):3-5.

Gibello A, Mata Al, Blanco MM, Casamayor A, Domínguez L, Fernández-Garayzabal JF: First Identification of Streptococcus phocae Isolated from Atlantic Salmon (Salmo salar). J Clin Microbiol 2005;43:526-527.

Gildberg A, Mikkelsen, H: Effects of supplementing the feed to Atlantic cod (Gadus morhua) fry with lactic acid bacteria and immuno-stimulating peptides during a challenge trial with Vibrio anguillarum. Aquaculture 1998;167:103-113.

González CJ, Encinas JP, García-López ML, Otero A: Characterization and identification of lactic acid bacteria from freshwater fishes. Food Microbiol 2000;17:383-391.

Hagi T, Tanaka D, Iwamura Y, Hoshino T: Diversity and seasonal changes in lactic acid bacteria in the intestinal tract of cultured freshwater fish. Aquaculture 2004;234: 335-346.

Halami PM, Chandrashekar A, Joseph R: Characterization of bacteriocinogenic strains of lactic acid bacteria in fowl and fish intestines and mushroom. Food Biotechnol 1999;13:121-136.

Huber I, Spanggaard B, Appel KF, Rossen L, Nielsen T, Gram L: Phylogenetic analysis and in situ identification of the intestinal microbial community of rainbow trout (Oncorhynchus mykiss, Walbaum). J Appl Microbiol 2004;96:117-132.

Irianto A, Austin B: Use of probiotics to control furunculosis in rainbow trout, Oncorhynchus mykiss (Walbaum). J Fish Dis 2002;25:333-342.

Irianto A, Austin B: Use of dead probiotic cells to control furunculosis in rainbow trout, Oncorhynchus mykiss (Walbaum). J Fish Dis 2003;26:59-62.

Jöborn A, Dorsch M, Olsson JC, Westerdahl A, Kjelleberg S: Carnobacterium inhibens sp nov., isolated from the intestine of Atlantic salmon (Salmo salar). Int J Syst Bacteriol 1999;49:1891-1898.

Lara-Flores M, Olvera-Novoa MA, Guzmán-Méndez BE, López-Madrid W: Use of the bacteria Streptococcus faecium and Lactobacillus acidophilus, and the yeast Saccharomyces cerevisiae as growth promoters in Nile tilapia (Oreochromis niloticus). Aquaculture 2003;216:193-201.

Lowther A: Highlights from the FAO database on aquaculture production statistics. FAO Aquaculture Newsletter 2005;33:22-24.

Métivier A, Boyaval P, Duffes F, Dousset X, Compoint JP, Marion D: Triton X-114 phase partitioning for the isolation of a pediocin-like bacteriocin from Carnobacterium divergens. Lett Appl Microbiol 2000;30:42-46. 
Mohanty SN, Swain SK, Tripathi SD: Rearing of catla (Catla catla Ham.) spawn on formulated diets. J Aqua Trop 1996;11:253-258.

Nikoskelainen S, Salminen S, Bylund G, Ouwehand AC: Characterization of the properties of human- and dairy-derived probiotics for prevention of infectious diseases in fish. Appl Environ Microbiol 2001a;67:2430-2435.

Nikoskelainen S, Ouwehand AC, Salminen S, Bylund G: Protection of rainbow trout (Oncorhynchus mykiss) from furunculosis by Lactobacillus rhamnosus. Aquaculture 2001b;198:229-236.

Nikoskelainen S, Ouwehand AC, Bylund G, Salminen S, Lilius EM: Immune enhancement in rainbow trout (Oncorhynchus mykiss) by potential probiotic bacteria (Lactobacillus rhamnosus). Fish Shellfish Immunol 2003;15:443-452.

Nilsson L, Nielsen MK, Ng Y, Gram L: Role of acetate in production of an autoinducible class IIa bacteriocin in Carnobacterium piscicola A9b. Appl Environ Microbiol 2002;68:2251-2260.

Ottesen $\mathrm{OH}$, Olafsen JA: Effects on survival and mucous cell proliferation of Atlantic halibut, Hippoglossus hippoglossus L., larvae following microflora manipulation. Aquaculture 2000;187:225-238.

Panigrahi A, Kiron V, Kobayashi T, Puangkaew J, Satoh S, Sugita H: Immune responses in rainbow trout Oncorhynchus mykiss induced by a potential probiotic bacteria Lactobacillus rhamnosus JCM 1136. Vet Immunol Immunopathol 2004;102:379-388.

Panigrahi A, Kiron V, Puangkaew J, Kobayashi T, Satoh S, Sugita H: The viability of probiotic bacteria as a factor influencing the immune response in rainbow trout Oncorhynchus mykiss. Aquaculture 2005;243:241-254.

Pasnik DJ, Evans JJ, Panangala VS, Klesius PH, Shelby RA, Shoemaker CA: Antigenicity of Streptococcus agalactiae extracellular products and vaccine efficacy. J Fish Dis 2005a;28:205-212.

Pasnik DJ, Evans JJ, Klesius PH: Abstract Duration of protective antibodies and correlation with survival in Nile tilapia Oreochromis niloticus following Streptococcus agalactiae vaccination. Dis Aquat Organ 2005b;66:129-34.

Pasnik DJ, Evans JJ, Klesius PH: Passive immunization of Nile tilapia (Oreochromis niloticus) provides significant protection against Streptococcus agalactiae. Fish Shellfish Immunol DOI: 10.1016/j.fsi.2006.01.001.

Petersen A, Dalsgaard A: Antimicrobial resistance of intestinal Aeromonas spp. and Enterococcus spp. in fish cultured in integrated broiler-fish farms in Thailand. Aquaculture 2003:219;71-82.

Picchietti S, Mazzini M, Taddei AR, Renna R, Fausto AM, Mulero V, Carnevali O, Cresci A, Abelli L: Effects of administration of probiotic strains on GALT of larval gilthead seabream: immunohistochemical and ultrastructural studies. Fish Shellfish Immunol DOI: 10.1016/j.fsi.2006.03.009.

Ringø E: Does Carnobacterium divergens isolated from Atlantic salmon, Salmo salar L., colonize the gut of early developing turbot, Scophthalmus maximus L., larvae? Aquac Res 1999;30:229-232.

Ringø E, Gatesoupe FJ: Lactic acid bacteria in fish: a review. Aquaculture 1998;160:177-203.

Ringø E, Holzapfel W: Identification and characterization of carnobacteria associated with the gills of Atlantic salmon (Salmo salar L.). Syst Appl Microbiol 2000;23:523-527.

Ringø E, Olsen RE: The effect of diet on aerobic bacterial flora associated with intestine of Arctic charr (Salvelinus alpinus L.). J Appl Microbiol 1999;86:22-28.

Ringø E, Bendiksen HR, Wesmajervi MS, Olsen RE, Jansen PA, Mikkelsen H: Lactic acid bacteria associated with the digestive tract of Atlantic salmon (Salmo salar L.). J Appl Microbiol 2000;89:317-322.

Ringø E, Wesmajervi MS, Bendiksen HR, Berg A, Olsen RE, Johnsen T, Mikkelsen H, Seppola M, Strøm E, Holzapfel W: Identification and characterization of carnobacteria isolated from fish intestine. Syst Appl Microbiol 2001;24:183-191.

Ringø E, Lødemel JB, Myklebust R, Jensen L, Lund V, Mayhew TM, Olsen RE: The effects of soybean, linseed and marine oils on aerobic gut microbiota of Arctic charr Salvelinus alpinus L. before and after challenge with Aeromonas salmonicida ssp. salmonicida. Aquac Res 2002a;33:591-606. 
Ringø E, Seppola M, Berg A, Olsen RE, Schillinger U, Holzapfel W: Characterization of Carnobacterium divergens strain 6251 isolated from intestine of Arctic Charr (Salvelinus alpinus L.). Syst Appl Microbiol 2002b;25:120-129.

Robertson PAW, O'Dowd C, Burrells C, Williams P, Austin B: Use of Carnobacterium sp as a probiotic for Atlantic salmon (Salmo salar L.) and rainbow trout (Oncorhynchus mykiss, Walbaum). Aquaculture 2000;185:235-243.

Ruiz Zarzuela I, de Blas I, Gironés O, Ghittino C, Múzquiz, JL: Isolation of Vagococcus salmoninarum in rainbow trout, Oncorhynchus mykiss (Walbaum), broodstocks: Characterization of the pathogen. Vet Res Commun 2006;29:553-562.

Salinas I, Cuesta A, Esteban MA, Meseguer J: Dietary administration of Lactobacillus delbrueckii and Bacillus subtilis, single or combined, on gilthead seabream cellular innate immune responses. Fish Shellfish Immunol 2005;19:67-77.

Salinas I, Díaz-Rosales P, Cuesta A, Meseguer J, Chabrillón M, Moriñigo MA, Esteban MA: Effect of heat-inactivated fish and non-fish derived probiotics on the innate immune parameters of a teleost fish (Sparus aurata L.). Vet Immunol Immunopathol DOI: 10.1016/j.vetimm.2006.01.020.

Semedo T,Almeida Santos M, Silva Lopes-MF, Figueiredo Marques-JJ, Barreto Crespo-MT, Tenreiro-R: Virulence factors in food, clinical and reference enterococci: A common trait in the genus? Syst Appl Microbiol 2003;26:13-22.

Seppola M, Olsen RE, Sandaker E, Kanapathippillai P, Holzapfel W, Ringø E: Random amplification of polymorphic DNA (RAPD) typing of carnobacteria isolated from hindgut chamber and large intestine of Atlantic cod (Gadus morhua I.). Syst Appl Microbiol 2006;29:131-137.

Silva FCP, Brito MFG, Farias LM, Nicoli JR: Composition and antagonistic activity of the indigenous intestinal microbiota of Prochilodus argenteus Agassiz. J Fish Biol 2005;67:1686-1698.

Sommerset I, Krossoy B, Biering, E, Frost, P: Vaccines for fish in aquaculture. Expert Rev Vaccines 2005;4:89-101.

Spanggaard B, Huber I, Nielsen J, Nielsen T, Appel KF, Gram L: The microflora of rainbow trout intestine: a comparison of traditional and molecular identification. Aquaculture 2000;182:115.

Spanggaard B, Huber I, Nielsen J, Sick EB, Pipper CB, Martinussen T, Slierendrecht WJ, Gram $\mathrm{L}$ : The probiotic potential against vibriosis of the indigenous microflora of rainbow trout. Environ Microbiol 2001;3:755-765.

Sugita H, Okano R, Suzuki Y, Iwai S, Mizukami M, Akiyama N, Matsuura S: Antibacterial abilities of intestinal bacteria from larval and juvenile Japanese flounder against fish pathogens. Fisheries Sci 2002;68:1004-1011.

Swain SK, Rangacharyulu PV, Sarkar S, Das KM: Effect of a probiotic supplement on growth, nutrient utilization and carcass composition in mrigal fry. J Aqua 1996;4:29-35.

Taoka Y, Maeda H, Jo JY, Jeon MJ, Bai SC, Lee WJ, Yuge K, Koshio S: Growth, stress tolerance and non-specific immune response of Japanese flounder Paralichthys olivaceus to probiotics in a closed recirculating system. Fisheries Sci 2006;72:310-321.

Tomé E, Teixeira P, Gibbs PA: Anti-listerial inhibitory lactic acid bacteria isolated from commercial cold smoked salmon. Food Microbiol 2006;23:399-405.

Vázquez JA, Cabo ML, González MP, Murado MA: Survival of lactic acid bacteria in seawater: A factorial study. Curr Microbiol 2003;47:508-513.

Vázquez JA, González MP, Murado MA: Effects of lactic acid bacteria cultures on pathogenic microbiota from fish. Aquaculture 2005;245:149-161.

Villamil L, Tafalla C, Figueras A, Novoa B: Evaluation of immunomodulatory effects of lactic acid bacteria in turbot (Scophthalmus maximus). Clin Diagn Lab Immunol 2002;9:1318-1323.

Vine NG, Leukes WD, Kaiser $\mathrm{H}$ : In vitro growth characteristics of five candidate aquaculture probiotics and two fish pathogens grown in fish intestinal mucus. FEMS Microbiol Lett 2004;231:145-152. 